\title{
Assessment of Communication Skills among Nurse Interns' Students of Technical Institute of Nursing during Health Teaching at Suez- Canal University Hospitals
}

\author{
Nashwa Abd El-Kawi Abd El-Havez, Wafaa Abd El-Azeem El-Hosany, Nadia \\ Mohamed El-Sayed Ghonem,
}

Clinical Instructor, School of Nursing, Ismailia City, Assistant Professor of Nursing

Administration, Faculty of Nursing, Suez-Canal University,Lecturer of Nursing

Administration, Faculty of Nursing, Suez Canal University

\begin{abstract}
Background: Health professional requires communication skills to establish and maintain effective helping relationships with patients and with each others. Aim: The current study aimed to assess communication skills among nurse interns' students of Teaching Institute of Nursing during health teaching at Suez Canal University Hospitals. Subjects \& Methods: A descriptive design was utilized to meet the aim of the research. The study conducted in different departments and units at Suez Canal University Hospitals. All nurse interns' students (84 students) included in this study. They entered the internship program after they pass the fifth-year examination in Technical Institute of Nursing (five-year system). The data collected by using an observational checklist. Results: Among 84 nurse interns' students, the majority of them were female, single, less than 20 years old and live in urban areas ( $56.0 \%$, $83.3 \%, 97.6 \%$ and $60.7 \%$ ) respectively and two-thirds of respondents $(60.7 \%)$ had unsatisfactory results for the communication skills while $(39.3 \%)$ of them just got satisfactory results, in addition to this, that most of the students did not satisfactory results on self-preparation and skills of verbal communication during the health education process. conclusions : the majority of the nurse interns' students had inadequate total preparation, verbal and overall communication skills. But, most of them have satisfactory non- verbal communication skills during health teaching with a statistical significant correlation between some of the communication skills among nurse interns' students and their gender and residence. Recommendations: Preparing students to interact and create constructive communicative relationships with patients is essential to nursing practice. In addition, the curriculum must be included verbal, and non-verbal communication skills in details and students must practice it.
\end{abstract}

Keywords: Communication skills, health teaching, nurse interns' students. 


\section{INTRODUCTION}

Communication defined as the exchange of ideas or information between group and individuals to achieve mutual understanding (Bastable, 2008). Communication skills promote healthy relationship among people. They are essential in leading managing and working with other. As well as, health care professionals require these skills to establish, maintain, and terminate effective helping relationships with patients, and to develop and maintaining a collaborative relationship with each other's (Papagiannis, 2010; Kourkouta \& Papathanasiou, 2014). Although communication may take many forms there are two types; verbal and non-verbal; Verbal communication may take the form of written messages or oral communication which can be face to face or telephone calls. Non-verbal communication includes body language, facial expressions, and touching (Burgoon, Guerrero, \& Manusov, 2011).

Communication skills are a particularly important aspect of health that students need to learn. Health teaching is not an educational frill it is necessity refers to any healthrelated educational activities, with clear goals planning for the purpose of improving health-related knowledge, attitude or behavior whether in schools, communication or work setting (Redman, 2007).

The goals of a therapeutic relationship focus on the clients achieving optimal personal growth and assessment of a client ability to communicate includes gathering data about the many contextual factors that influence communication the word context refers to all the parts of something that help determine its meaning. Therapeutic interactions augment feeling of individual control by helping the person feel secure, informed and valued. Optimizing own control facilitates emotional comfort, which minimizes physical discomfort and enhances recovery activities (Polit \& Beck, 2013).

The internship is a planned supervised experience in an agency whereby the student nurse gains practical work experience. It bridges the gap that graduate has to cross when moving from the school world and interring the work world. It eases the adjustment to staff position purposes to ensure that the recent graduates possess enough clinical information to $\mathrm{Be}$ able to translate nursing theory into practice (Levett-Jones \& Bourgeois, 2015).

he nursing internship involves an educational experience that provides a transition from student to practitioner. Also, it provides skills in the area of nursing management as well as clinical practice. Nurse interns integrate and apply all the skills they learned during schooling in a real situation even under supervision. Also, they acquire more technical expertise and knowledge as well as adjust to the work setting (Gaarder, Eide, \& Falck, 2000). 


\section{Significant of the study:}

Communication skills play a vital role in improving the nurse-patient relationship and the provided health services. As well as, the nurse interns give health teaching to the patient during his/her internship period, but the most of them have not communication skills and don't know how to communicate with patients and transfer the information to them. In the light of this, the present study was aimed to assess communication skills among nurse interns' students of Technical Institute of Nursing during health teaching at Suez Canal University hospitals.

\section{AIM OF THE STUDY:}

The aim of the present study was to assess communication skills among nurses' interns of Technical Institute of Nursing during health teaching.

\section{Research question:}

Are nurse interns' students of Technical Institute of nursing having satisfactory communication skills during health teaching at Suez- Canal University hospitals?

\section{SUBJECTS AND METHODS :}

\section{Study design:}

A descriptive study design was used in this study.

\section{Study setting:}

This study conducted at Suez Canal University Hospitals in the different departments and units as; Internal Medicine, Pediatrics, General Surgery, Urology, Obstetrics and Gynecology, Oncology and Nuclear Medicine, Orthopedics, One-day Surgery, Neurosurgery, Nephrology, and Dialysis Unit, and Neurology departments and outpatient clinics at Suez Canal University Hospitals.

\section{Subjects:}

The study was carried out on all available nurse interns' students (84 students) after they passed the fifth year examination in Technical Institute of Nursing (five-year system). They spent their internship period in the same previous study settings.

\section{Tools of data collection:}

The data collected by using an observation checklist, it developed by Abd Elsalam, (1999) to assess the communication skills among nurse interns' students during health teaching. This tool consisted of two parts:

- Part I: This part included socio- demographic of study group. Such as: name, 
age, gender, residence, marital status, the paternal and maternal education, paternal and maternal occupation and the departments/units.

- Part II: this part used to measure Communication skills among nurse interns' students ; it consisted of 74 items are presented according to three major domains as follow:

oDomain 1: Preparation for communication; including four subdomains; selfpreparation (5 sub-items), environmental-preparation (5 sub-items), sender introduction ( 9 sub-items), and receiver-preparation ( 5 sub-items).

oDomain 2: Verbal communication skills; including three subdomains; delivering the message and its method (13 sub-items), closure (7 sub-items), and voice characteristics (5 sub-items).

Domain 3: Non-verbal communication skills; including four Subdomains. Appearance (4 sub-items), movements ( 5 sub-items), body language ( 7 subitems), and listening (9 sub-items).

Scoring: For each part of the tool, the points are summed-up and divided by the number of items to provide a mean score. The scores are presented in terms of means and standard deviations. The total score calculated in every domain. The participants considered as having unsatisfactory scores if percent score was $<60 \%$ and they having satisfactory scores if percent score was $\geq 60 \% \operatorname{Shabaan}(\mathbf{2 0 0 3})$.

Pilot study: A pilot study was carried out on $10 \%$ (8 students) from the study sample to check and ensure the clarity and applicability of the tool and feasibility of the study, and to estimate the approximate time needed filling the form. Necessary changes in the tool were done according to pilot results and the piloted sample was included in the main study sample.

Field work: Before data collection, face and content validity of the questionnaire through rigorous review by a group of experts in the nursing administration were ascertained. The group consisted of 3 faculty members, from the Faculty of Nursing at Suez-Canal University. Their comments factored into fine tuning of the tool.

The researcher provided nurse interns' students with a short orientation to describe the nature of the study and invited them to participate. Those who consented were set in groups of 10-15 for students. Filling the questionnaire was done by each individual participant in the presence of the researcher to ensure that the forms are filled without interactions during the process, so as to avoid being influenced by each others. The process of data collection lasted for three months from the beginning of December 2012 to ending of February 2013.

\section{ADMINISTRATIVE DESIGN:}

Official letters were sent from the dean of the faculty of nursing at Suez Canal University to the directors of study settings, explaining the aim of the study and the expected outcome to take their permission to carry out the research. Official 
permission for collection of data was obtained using proper channels of communication to conduct the study, with acceptance of directors of Suez Canal University Hospitals and director of Technical Institute of Nursing (5 years system) at Suez Canal University.

Each student was asked to give verbal consent to participate in the study after full explanation of nature and the main aim of the study and its expected outcomes benefits. Each participant was free to either participate or not in this study and had the right to withdrawal from the study at any time without any rationale.

\section{STATISTICAL DESIGN:}

Upon completion of data collection variable included in each data, collection sheet was organized and tabulated then coded before computerized data entry. The data then imported into IBM Statistical Package for the Social Sciences (IBM SPSS version 20.0) software for statistical analysis. The quantitative data presented as means and standard deviation (SD), and the qualitative data presented as frequency and percentage. Student t-test used to evaluate the least significance difference between groups. Probability level (p-value) of 0.05 adopted as the degree of significance for testing hypothesis.

\section{RESULTS:}

Table (1): shows that the majority of students were female, single, less than 20 years old and lives in urban areas $(56.0 \%, 83.3 \%, 97.6 \%$ and 60.7\%) respectively. And also, the most of students' fathers work manual jobs with primary and secondary education $(41.7 \%$ and $58.3 \%)$ respectively and the majority of students' mothers were unemployed and illiterate, read and write $(85.7 \%$ and $59.5 \%)$ respectively. As well as $(13.0 \%)$ of the students were trained in internal medicine department and $(3.6 \%)$ of them were trained in nephrology and dialysis units and neurology department.

Table (2): shows that the mean value of total preparation among the included students was ranged from 3.14 for self- preparation to (4.39) for Sender introduction and the mean value of total verbal communication skills was ranged from 2.76 for Closure to (7.25) for Massage delivery, the mean value of total non-verbal communication skills was ranged from 3.37 for Movements to 11.13 for Listening

Table (3): shows that the most unsatisfactory communication domain among the included students was total preparation $(60.7 \%)$, while the most satisfactory communication domain was non-verbal skills $(72.6 \%)$. Totally, the majority of the nursing interns had unsatisfactory communication skills $(60.7 \%)$, while $39.3 \%$ of them had satisfactory communication skills.

Table (4): illustrates that female students had significantly higher mean values of total preparation, voice characteristics, movements and total non-verbal communication skills, while male students had significantly higher mean values of message delivery. 
Table (5): reveals that there were statistically significant higher mean values of total preparation in the students who lived in urban areas, while there were statistically significant higher mean values of non-verbal communication skills (appearance) in the students who lived in rural areas.

Table (1): Distribution of study sample according to their Socio-demographic characteristics $(n=84)$

\begin{tabular}{|c|c|c|}
\hline \multirow{2}{*}{ Variables } & \multicolumn{2}{|c|}{ Study population $(n=84)$} \\
\hline & No & $\%$ \\
\hline \multicolumn{3}{|l|}{ Age (years) } \\
\hline$<20$ years & 82 & 97.6 \\
\hline$>20$ years & 2 & 2.4 \\
\hline Mean \pm SD & \multicolumn{2}{|c|}{$20.2 \pm 0.15$} \\
\hline \multicolumn{3}{|l|}{ Gender } \\
\hline Female & 47 & 56.0 \\
\hline Male & 37 & 44.0 \\
\hline \multicolumn{3}{|l|}{ Residence } \\
\hline Urban & 51 & 60.7 \\
\hline Rural & 33 & 39.3 \\
\hline \multicolumn{3}{|l|}{ Marital status } \\
\hline Single & 70 & 83.3 \\
\hline Married & 14 & 16.7 \\
\hline \multicolumn{3}{|l|}{ Paternal education } \\
\hline Illiterate /read \& write & 26 & 31.0 \\
\hline Primary/secondary & 49 & 58.3 \\
\hline University & 9 & 10.7 \\
\hline \multicolumn{3}{|l|}{ Maternal education } \\
\hline Illiterate /read \& write & 50 & 59.5 \\
\hline Primary/secondary & 28 & 33.3 \\
\hline University & 6 & 7.1 \\
\hline \multicolumn{3}{|l|}{ Paternal occupation } \\
\hline Professional job & 9 & 10.7 \\
\hline Official job & 34 & 40.5 \\
\hline Manual job & 35 & 41.7 \\
\hline Retied & 6 & 7.1 \\
\hline \multicolumn{3}{|l|}{ Maternal occupation } \\
\hline Unemployed & 72 & 85.7 \\
\hline Employed & 12 & 14.3 \\
\hline \multicolumn{3}{|l|}{ Departments / Units } \\
\hline Internal Medicine & 11 & 13.0 \\
\hline Pediatrics & 10 & 11.9 \\
\hline General Surgery & 10 & 11.9 \\
\hline Urology & 10 & 11.9 \\
\hline Obstetrics and Gynecology & 8 & 9.5 \\
\hline Oncology and Nuclear Medicine & 8 & 9.5 \\
\hline Orthopedics & 7 & 8.3 \\
\hline One-day Surgery & 5 & 6.0 \\
\hline Outpatient clinics & 5 & 6.0 \\
\hline Neurosurgery & 4 & 4.8 \\
\hline Nephrology and Dialysis Unit & 3 & 3.6 \\
\hline Neurology & 3 & 3.6 \\
\hline
\end{tabular}


Table (2): Mean values of communication skills among the study subjects $(n=84)$ :

\begin{tabular}{|l|c|c|}
\hline \multirow{2}{*}{\multicolumn{1}{|c|}{ Variables }} & \multicolumn{2}{c|}{ Study population (n=84) } \\
\cline { 2 - 3 } & Mean & SD \\
\hline Self-preparation (0-5) & 3.14 & 1.69 \\
\hline Environmental-preparation (0-5) & 3.92 & 1.76 \\
\hline Sender introduction (0-9) & 4.39 & 2.46 \\
\hline Receiver-preparation (0-5) & 3.56 & 1.43 \\
\hline Total preparation (0-24) & $\mathbf{1 4 . 0 1}$ & $\mathbf{5 . 7 2}$ \\
\hline Message delivery (0-13) & 7.25 & 3.23 \\
\hline Closure (0-7) & 2.76 & 1.78 \\
\hline Voice characteristics (0-5) & 4.23 & 1.24 \\
\hline Total verbal communication skills (0-25) & $\mathbf{1 4 . 2 4}$ & $\mathbf{5 . 1 3}$ \\
\hline Appearance (0-4) & 3.42 & 1.03 \\
\hline Movements (0-5) & 3.37 & 1.78 \\
\hline Body language (0-7) & 5.07 & 2.21 \\
\hline Listening (0-9) & 11.13 & 4.56 \\
\hline Total non-verbal communication skills (0-25) & $\mathbf{1 7 . 9 2}$ & $\mathbf{6 . 5 4}$ \\
\hline Total communication skills (0-74) & $\mathbf{4 3 . 2 0}$ & $\mathbf{1 5 . 6 0}$ \\
\hline
\end{tabular}

Table (3): Communication skills of the included students according to satisfactory level $(n=84)$ :

\begin{tabular}{|l|c|c|c|c|}
\hline \multirow{2}{*}{\multicolumn{1}{|c|}{ Variables }} & \multicolumn{4}{c|}{ Study population (n=84) } \\
\cline { 2 - 5 } & \multicolumn{2}{|c|}{ Satisfactory } & \multicolumn{2}{c|}{ Unsatisfactory } \\
\cline { 2 - 5 } & No. & \% & No. & \% \\
\hline Self-preparation & 27 & 32.1 & 57 & 67.9 \\
\hline Environmental-preparation & 20 & 23.8 & 64 & 76.2 \\
\hline Sender introduction & 43 & 51.2 & 41 & 48.8 \\
\hline Receiver-preparation & 23 & 27.4 & 61 & 72.6 \\
\hline TOTAL PREPARATION & 33 & 39.3 & 51 & 60.7 \\
\hline Massage delivery & 41 & 48.8 & 43 & 51.2 \\
\hline Closure & 66 & 78.6 & 17 & 20.2 \\
\hline Voice characteristics & 12 & 14.3 & 72 & 85.7 \\
\hline TOTAL VERBAL & 41 & 48.8 & 43 & 51.2 \\
\hline Appearance & 71 & 84.5 & 13 & 15.5 \\
\hline Movements & 61 & 72.6 & 23 & 27.4 \\
\hline Body language & 55 & 65.5 & 29 & 34.5 \\
\hline Listening & 58 & 69.0 & 26 & 31.0 \\
\hline TOTAL NON-VERBAL & 61 & 72.6 & 23 & 27.4 \\
\hline TOTAL COMMUNICATION & 33 & 39.3 & 51 & 60.7 \\
\hline
\end{tabular}

Satisfactory ( $\geq 60 \%)$, unsatisfactory $(<60 \%)$. 
Table (4): correlation between items of communication skills and students' gender $(n=84)$

\begin{tabular}{|c|c|c|c|c|c|c|}
\hline \multirow{2}{*}{ Variables } & \multicolumn{2}{|c|}{ Males (n=37) } & \multicolumn{2}{|c|}{ Females $(n=47)$} & \multirow[t]{2}{*}{ t-test } & \multirow[t]{2}{*}{ p-value } \\
\hline & Mean & SD & Mean & SD & & \\
\hline Self-preparation & 3.0 & 1.7 & 3.3 & 1.7 & 0.75 & 0.45 \\
\hline Environmental-preparation & 4.1 & 1.6 & 3.8 & 1.9 & 0.77 & 0.44 \\
\hline Sender introduction & 3.97 & 2.2 & 4.7 & 2.7 & 1.33 & 0.19 \\
\hline Receiver-preparation & 3.8 & 1.2 & 3.4 & 1.6 & 1.32 & 0.20 \\
\hline Total preparation & 11.8 & 4.8 & 15.2 & 6.4 & 2.7 & $0.009 * *$ \\
\hline Massage delivery & 7.5 & 3.0 & 6.0 & 3.4 & 2.1 & $0.038 *$ \\
\hline Closure & 3.2 & 1.9 & 2.5 & 1.7 & 1.8 & 0.08 \\
\hline Voice characteristics & 3.2 & 1.2 & 4.2 & 1.3 & 3.6 & $0.0005^{* *}$ \\
\hline Total verbal communication & 14.8 & 4.7 & 13.8 & 5.4 & 0.89 & 0.38 \\
\hline Appearance & 3.4 & 0.9 & 3.5 & 1.1 & 0.45 & 0.65 \\
\hline Movements & 2.4 & 1.7 & 3.4 & 1.9 & 2.5 & $0.014^{*}$ \\
\hline Body language & 4.95 & 2.2 & 5.2 & 2.2 & 0.51 & 0.61 \\
\hline Listening & 10.8 & 4.5 & 11.4 & 4.595 & 0.60 & 0.55 \\
\hline Total non-verbal communication & 20.0 & 7.2 & 23.4 & 7.97 & 2.1 & $0.044^{*}$ \\
\hline Total communication & 52.1 & 15.2 & 52.3 & 19.3 & 0.05 & 0.84 \\
\hline
\end{tabular}

*Significant $\mathrm{p}$-value $<0.05, * *$ highly significant $\mathrm{p}$-value $<0.01$.

Table (5): Correlation between items of communication skills and students' residence $(\mathrm{n}=84)$

\begin{tabular}{|l|c|c|c|c|c|c|}
\hline \multirow{2}{*}{ Variables } & \multicolumn{2}{|c|}{ Urban $(\mathbf{n}=51)$} & \multicolumn{2}{c|}{ Rural (n=33) } & \multirow{2}{*}{ t-test } & \multirow{2}{*}{ p-value } \\
\cline { 2 - 6 } Self-preparation & Mean & SD & Mean & SD & & \\
\hline Environmental-preparation & 3.1 & 1.2 & 3.4 & 1.3 & 0.85 & 0.55 \\
\hline Sender introduction & 3.9 & 1.4 & 4.0 & 1.2 & 0.90 & 0.46 \\
\hline Receiver-preparation & 4.3 & 2.1 & 4.6 & 2.4 & 1.35 & 0.18 \\
\hline Total preparation & 4.2 & 1.1 & 3.99 & 1.4 & 1.34 & 0.21 \\
\hline Massage delivery & 12.1 & 3.8 & 10.2 & 4.4 & 3.0 & $0.001^{* *}$ \\
\hline Closure & 6.5 & 3.1 & 6.3 & 3.3 & 1.1 & 0.38 \\
\hline Voice characteristics & 3.4 & 1.7 & 3.2 & 1.5 & 1.5 & 0.1 \\
\hline Total verbal & 3.4 & 0.9 & 3.5 & 1.1 & 0.45 & 0.65 \\
\hline Appearance & 15.0 & 5.0 & 14.7 & 5.2 & 0.9 & 0.4 \\
\hline Movements & 3.0 & 1.0 & 3.9 & 1.2 & 2.2 & $0.005^{* *}$ \\
\hline Body language & 3.4 & 1.4 & 3.6 & 2.0 & 1.6 & 0.14 \\
\hline Listening & 5.0 & 2.0 & 4.9 & 2.1 & 0.1 & 0.6 \\
\hline Total non-verbal & 11.0 & 5.0 & 11.1 & 5.1 & 0.6 & 0.7 \\
\hline Total communication & 21.6 & 6.2 & 22.0 & 6.7 & 1.1 & 0.44 \\
\hline
\end{tabular}

*Significant p-value $<0.05, * *$ highly significant $\mathrm{p}$-value $<0.01$. 


\section{DISCUSSION:}

Communication is the procedure of exchanging information and generating and transmitting meanings between two or more persons. It is the basis of society and the most important aspect of a nurse-patient interaction. Without communication, it would be impossible to share family experiences, gain knowledge, establish and maintain practice protocols Wade \& Hayes, (2010) and Kourkouta \& Papathanasiou (2014).

The findings of the present study agreed with, Kruijver et al., (2000); Chant et al., (2002) and Mullan and Kothe (2010) reported that despite the recognized importance of nurse communication skills and practice. Researchers suggested that the quality of new nurses' communication skills remain an ongoing concern in nursing practice.

The present study illustrated that the students had poor scores in total preparation and verbal communication skills. It may due to the students are young aged and unprepared for the depth of knowledge. Also, the study of Newton and McKenna (2007) observed that the nursing student is often unprepared for the depth of knowledge and communication skills required to work in specialist areas.

Meanwhile, the most satisfactory communication domain was non-verbal skills about two third of study sample. This due to the students mainly begins the conversation with the patients without any previous preparation, which had a severe impact on the course of communication. It also observed that verbal communication was affected more than non-verbal communication. This finding indicates that the students were concerned with their good appearance and appropriate movements more than their adequate words and ideas. The present study showed that the majority of the students had poor scores regarding subdomains self-preparation, environmental-preparation, receiver-preparation, message delivery, and voice characteristics. It may be due to the nurse student haven't sufficient trained.

Regarding the correlations between communication skills and socio-demographic characteristics, the finding of the study agrees with Hargie and Tourish (2009). Studies of gender-related communication behaviors suggested that women prefer nonverbal communication like touch and gesture. They smile more frequently. Social skills inventories have revealed consistent gender differences on various dimensions, females scoring higher on measures of non-verbal emotional expressivity and sensitivity.

In the same line of the results of the present study, Arnold and Boggs (2006) reported that males prefer to be more directive, self-opinionated and explicit, whereas females tend to be more indirect, use greater soft speech styles and refer more to emotions. There are inconsistencies in the studies reporting these behaviors 
And in the same direction of the present results Arnold and Boggs (2015) suggested that when men and women interact within a context of gender inequality, barriers to communication and interpersonal relationships can inhibit adequate assessment and health interventions. The danger is that gender inequality can exacerbate or reinforce existing problems (for example, low self-esteem) and lack of opportunity to speak, describe or express ideas on issues. Well-practiced communication techniques alone are ineffectual if the central notion of the interpersonal connection goes unacknowledged

The results of the current study showed that female students had significantly higher mean values of total preparation, voice characteristics, movements and full non-verbal communication skills while male students had significantly higher mean values of message delivery. The same observed by the correlation between gender and items of communication skills of the included students.

This is due to that the females are concerned with their preparation, appearance, grooming, dressing, movements and other non-verbal skills. Also, their attractive voice characteristics may be one of the potential factors that significantly affect the communication. Meanwhile, the males had the ability to deliver the correct message at the proper time and place. In most societies, there are recognizable differences between men and women that have different expectations of behaviors and responses in social communications.

In addition, the finding of the present study showed that there was statistically significant correlation between total preparation skills and the students' residence (students who lived in urban areas) while there was statistically significant correlation between non-verbal communication skills (appearance) and the students' residence (students who lived in rural areas).

These findings may be due to that the urban individuals are concerned mainly with their preparation before meeting anyone. Meanwhile, the rural in a while, the rural individuals are concerned primarily with their appearance in front of other people, where the urbanization had crawled slowly into the depth of the rural regions, and the rural individuals become more and more urbanized by the time.

The presented study supported by Anderson, Calvillo, \& Fongwa, (2007) and Billings and Halstead (2013) who reported that acculturation represents an adaptive cultural process whereby biological, environmental and traditional forms of culture adapt to prevailing contextual mores, to survive or to maintain economic and social status. This observation can be seen in groups who have moved from an agricultural life to an urban existence or with continuous crawling of urbanization over the agricultural regions. 


\section{CONCLUSIONS:}

The results of the present study concluded that the majority of the nurse interns' students had inadequate total preparation, verbal and overall communication skills .But; they have satisfactory non- verbal communication skills during health education.

\section{RECOMMENDATIONS:}

Based on the results of the present study, the following recommendations were suggested that:

- Preparing the nurse interns' students to interact and create constructive communicative relationships with patients is essential in nursing practice.

- The educational curriculum must be included verbal, and non-verbal communication skills in details and students must practice it.

- Assertiveness is stressed composed of respect for others and oneself through consistent communication.

\section{REFERENCES :}

Abd ELsalam N., (1999): Assessment of Nurse Interns Communication skills in Health Teaching, Master Degree. Faculty of Nursing, Ain Shams University, Egypt.

Anderson, N. L. R., Calvillo, E. R., \& Fongwa, M. N. (2007): Community-based approaches to strengthen cultural competency in nursing education and practice. Journal of Transcultural Nursing, 18: 49S-59S.

Arnold, E. C., \& Boggs, K. U. (2006): Interpersonal Relationships: Professional communication skills for nurses $5^{\text {th }}$ ed. London: Elsevier. P. 23.

Arnold, E. C., \& Boggs, K. U. (2015): Interpersonal Relationships: Professional communication skills for nurses. $2^{\text {nd }}$ ed., Elsevier Health Sciences. PP. 33-50.

Bastable, S. B. (2008): Nurse as an educator. London: Jones \& Bartlett Publishers. PP. 18, 33 .

Billings, D. M., \& Halstead, J. A. (2013): Teaching in nursing: A guide for faculty. Elsevier Health Sciences. $3^{\text {rd }}$ ed., USA: Lippincott \&Williams, P.P.16, 31.

Burgoon, J. K., Guerrero, L. K., \& Manusov, V. (2011): Nonverbal signals. The SAGE handbook of interpersonal communication, PP. 239-280.

Chant, S., Jenkinson, T. I. M., Randle, J., \& Russell, G. (2002): Communication skills: some problems in nursing education and practice. Journal of clinical nursing, 11(4): $12-21$. 
Gaarder, K., Eide, N. A., \& Falck, G. (2000): Clinical skills among interns. Tidsskrift for den Norske Laegeforening: Tidsskrift for Praktisk Medicin, Ny Raekke, 12 (13): 1512-1517.

Hargie, O., \& Tourish, D. (Eds.). (2009): Auditing organizational communication: A handbook of research, theory and practice. Routledge.P. 33.

Kourkouta, L., \& Papathanasiou, I. V. (2014): Communication in nursing practice. Material Sociomedical, 11(2): 6, 65.

Kruijver, I. P., Kerkstra, A., Bensing, J. M., \& van de Wiel, H. B. (2000): Nursepatient communication in cancer care: a review of the literature. Cancer nursing, 23: 20-31.

Levett-Jones, T., \& Bourgeois, S. (2010): The clinical placement: An essential guide for nursing students. $6^{\text {th }}$ ed., Elsevier Health Sciences.P.P. 12,18.

Levett-Jones, T., \& Bourgeois, S. (2015): The clinical placement: An essential guide for nursing students. Elsevier Health Sciences, $2^{\text {nd }}$ ed., .USA: Lippincott Williams \& Wilkins, P.54.

Milton B. and Kothe E., (2010): Evaluating a nursing communication skills training course: The relationship between self- rated ability, satisfaction, and actual performance. Nurse Education in Practice, PP. 374- 378.

Newton, J. M., \& McKenna, L. (2007): The transitional journey through the graduate year: A focus group study. International journal of nursing studies, 44(7): 1231-1237.

Papagiannis, A. (2010): Talking with the patient: fundamental principles of clinical communication and the announcement of bad news. Medical Time Northwestern Greece, P.P.6, 43-49.

Polit, D. F., \& Beck, C. T. (2013): Essentials of nursing research: Appraising evidence for nursing practice. $5^{\text {th }}$ ed., USA: Lippincott Williams \& Wilkins.PP. 4472 .

Redman, B. K. (2007): The practice of patient education: a case study approach. Elsevier Health Sciences. $3^{\text {rd }}$ ed., London: Lippincott Williams \& Wilkins ,P.P.2225,70 .

Shabaan T., (2003): Assessing Students' communication Skills: Validation of a global Rating. Adv Health Sci Educ. Theory Pract, 13(5): 83- 92.

Wade, G. H., \& Hayes, E. (2010): Special features: education: challenges and opportunities associated with preceptors community health clinical experiences. Public Health Nursing, 27(5): 459-467. 
تقييم مهارة التواصل لاى طلاب امتياز المعهد الفنى للتمريض اثناء عملية التثقيف الصحى بمستثفيات جامعة قناة السويس

نشوى عبد القوى عبد الحافظ ، وفاء عبد العظيم الحسينى ، نادية محمد السيد غنيم

\section{الخلاصة}

ان مهارات الاتصال مهمة جدا فى المهن لإنشاء والحفاظ على علاقات فعالة مع المرضى ومع بعضهم البعض.، لذا فأن هذة الدراسة هدفت الى تقييم عملية التواصل بين طلاب امتياز المعهد الفنى للتمريض اثناء عملية التتقيف الصحى. استخدم المنهج الوصفي لأجراء هذه الدراسة. ونم اجراء هذة الدراسة بالعيادات

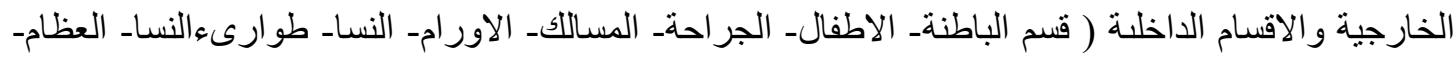

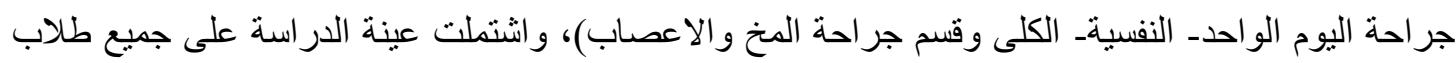
وطالبات الامتيازبالمعهد الفنى للتمريض نظام الخمس سنوات و عددهم ع^ طالب وطالبة ـ تم استخدام استمارة ملاحظة لجمع البيانات وتتكون من جز عين : الجزء الاول : يشمل بيانات شخصية لطلبة امتياز المعهذ الفنى للتمريض، و الجزء الثانى يتضمن مقياس لقياس مهارة التواصل لاى الطلاب اثناء الثقيف الصحى فى فترة التدريب العملى بالمستشفى. وقد اسفرت نتائج الدر اسة ومن بين ع^ طالبا مندربا كانت الغالبية العظمى منهم من

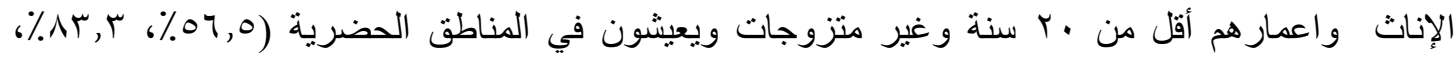

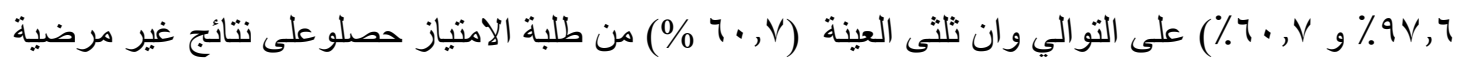

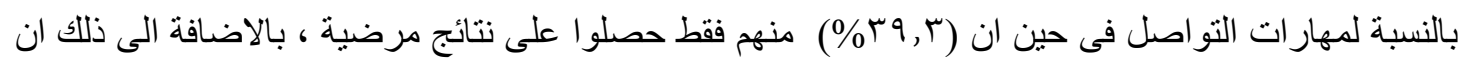
معظم الطلاب لم يحصلو على نتائج مرضية بشأن اعداد الذات ومهارات التو اصل اللفظية و الكلية اثثاء عملية

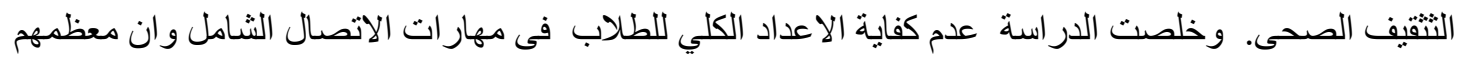
لايهم المهار ات اللفظية غير مرضية اثثاء التثقيف الصحى مع وجود علاقة ذات دلالة إحصائية بين بعض مهارات التواصل بين غالبية المتدربين وجنسهم و مكان إقامتهم كما اوصت الدراسة بضرورة اعداد الطالب للتفاعل مع المريض فبل التنريب العملى لتحقيق التواصل البناء، والتركيز على مهارة التواصل من مسؤلى و اضعى المناهج الدراسية الكلمات المرشدة: مهار ات التو اصل، التقفي الصحى، طلبة امتياز تمريض . 